\title{
CIBERATIVISM AS A POTENTIAL INSTRUMENTALIZATION OF NEW TACTICS OF POLITIC PARTICIPATION
}

\author{
O CIBERATIVISMO COMO POTENCIAL INSTRUMENTALIZAÇÃO DE NOVAS TÁTICAS DE \\ PARTICIPAÇÃO POLÍTICA
}

\begin{abstract}
Julio Trevisam Braga
Doutorando (bolsista CNPq), em História Social pela Pontifícia Universidade Católica de São Paulo. Mestre (bolsista CNPq), em História Social pela Pontifícia Universidade Católica de São Paulo. Historiador. Pesquisador em História, Direito e Democracia.

E-mail: julio.t.braga@gmail.com
\end{abstract}

Elisaide Trevisam

Doutora em Filosofia do Direito pela Pontifícia Universidade Católica de São Paulo. Mestre em Direitos Humanos. Especialista em Direito do Trabalho. Professora Visitante

Nacional do PPGD da Universidade Federal de Mato Grosso do Sul - UFMS. Pesquisadora nas áreas de Direitos Humanos e Filosofia do Direito.

E-mail: elis.trevi@hotmail.it

Recebido em: 24/01/2020

Aprovado em: 16/04/2020

\begin{abstract}
Given the founding principles of the Democratic Rule of Law, in this research we have the objective to reflect on how the interactions of public power with popular sovereignty were subjugated by the imposition of financial governance over the state autonomy, putting on defeat position the popular trust in political representativeness, with the technological influence on political participation. Nowadays, as the traditional means of protest and participatory instruments have become limited in their effectiveness of popular pressure, the advent of cyberactivism as a political practice has become a potential tool in managing social conflicts. On the other hand, a new profile of internet users (ordinary citizens) comes into play, making our reflection necessary to understand how the Big Data tool was appropriated to direct public opinion around election campaigns. This research used the dialectical method and was carried out through a bibliographic survey, seeking to dialogue with historical and legal concepts to understand the problem and the development of the objectives.
\end{abstract}

Keywords: Democracy and Cyberactivism. Political participation. Strategies and tactics. Democratic Rule of Law. Big Data and social empowerment.

RESUMO: Diante dos princípios fundadores do Estado Democrático de Direito, nesta pesquisa temos o objetivo de refletir a maneira como as interações do poder público com a soberania popular foram subjugadas pela imposição da governança financeira sobre a autonomia do Estado, colocando em xeque a confiança popular na representatividade política com a influência tecnológica na participação política. Atualmente, no momento que os tradicionais meios de 
protestos e instrumentos participativos tornaram-se limitados na sua eficácia de pressão popular, o advento do ciberativismo como prática política tornou-se um potencial instrumento de gestão dos conflitos sociais. Por outro lado, um novo perfil de usuários da internet (cidadãos comuns) entra em cena, tornando a nossa reflexão necessária para compreender como a instrumento do Big Data foi apropriado para direcionar a opinião pública em torno de campanhas eleitorais. Esta pesquisa utilizou o método dialético e foi realizada por meio de levantamento bibliográfico, buscando dialogar com conceitos históricos e legais para entender o problema e o desenvolvimento dos objetivos.

Palavras-chave: Democracia e Ciberativismo. Participação política. Estratégias e táticas. Estado Democrático de Direito. Big Data e empoderamento social.

SUMÁRIO: Introduction; 1 The erosion of representativeness in democracy facing the international economic agenda misdeeds; 2 Social movements, internet and the emergence of new political actors; 3 Cyberactivism as a new tactic of political participation?; Final Considerations; Bibliographic References.

\section{INTRODUCTION}

In the modern times world, at the turn of the 20s of the new century, technology no longer makes sense without being related to the our daily lives, being part of every moment we experience and being an active and vibrant channel of our emotions, which we no longer keep to ourselves or share with those close to us physically, but more than that, we make what we think, what we fear and what we call as a public good disclosure.

We could dedicate good pages to assess the impact of cyber technologies in all aspects of social life, but what interests us in this research is their influence, specifically, on the interactions experienced by political participation in the Democratic Rule of Law. In this sense, we stipulate as necessary to reflect on how the reality of the conflicts of a State named as democratic, in the modern world, is impacted by the intense use of technologies and, more precisely, by the practices of cyberactivism as a political instrument.

In order to being able to deal with this debate, we have as a diagnosis already given by the historical testimony - among the different theoretical aspects available and discussed in the long years that precede the present - that the realization of democratic values has not been effected yet in the sense we can conclude that the utopia of social justice has been realized - probably it will never be happen, in fact. However, we understand that what moves us to reach the democratic ideal is precisely the conflicting relationship that is expected in a democratic society, mutatis mutandis servatis servandis ${ }^{1}$.

Not wanting to affirm that economic aspects are those which defines human life in society, considering that aspects other than the economic sphere are, as well as it, crucial for the understanding of social relations and human relations with nature, we observe in this article however, that the economic influence on the States built over democratic ideals puts them in a condition, currently, that limit the States to concretely effect social justice.

More specifically, since the 1970s, the world has been managed and regulated by the profit variations of international financial speculation, where the minimalization of state power over the economy has made it hostage to the excesses of financial capital. In this way, the representation of the political class before the citizens in a democratic State also began to fall into disrepute, which puts in check the maintenance of popular sovereignty along the frames of representative democracy and which has long been the way of making politics in the modern world.

1 "Changing what should be changed, conserving what should be conserved".

Revista de Direito Brasileira | Florianólopis, SC | v. 25 | n. 10 | p. 104-119 | Jan./Abr. 2020 
In the first part of the article, in order to deepen this debate, we will discuss how the imposition of financial governance on the political governance of the State turned the interactions of public power with popular sovereignty, previously conflicted, into a weakened conformity with inequalities and submission to variations in profit to the financial speculation.

Starting from examples of social movements such as the Arab Spring, the Pot and Pans Revolution in Iceland, the Indignados in Spain, the Occupy Wall Street in the USA, and the June 2013 Days in Brazil, we will even show how, after having experienced the interplay of these movements with the internet, it is possible to take in evidence that a large part of the impellent that drives political life in democratic countries originates today in a population with a decentralized profile and not organized in social base movements.

Since the traditional means of street protests, through demonstrations and strikes, have increasingly become, not inefficient, but limited in their possibilities, the "lenses" of the internet that we have been gradually used to use for reading reality comes into play in the democracy of the new millennium and, as a complex and specific phenomenon in the modern world, cyberactivism has become a new instrument used to manage social conflicts. Therefore, in the second part of the article, we aim to discuss how social movements, after the 2008 crisis, started using social networks to publicize and mobilize society in order to face social injustices and against the inequal regulation of the financial strategies.

Based on the reflection that the development of new forms of political participation and the creation of new forms of interaction between governments and society will appear in this scenario, in an intense way, at the end we will demonstrate how the appropriation of Big Data as an instrument of analysis of data information allows to show that not only the social movements acquire new tactics of confrontation, but also the public power and those that move the financial speculations also adapt themselves to new strategies of containment and conservation of the submitted power over the democratic life.

Finally, to achieve the desired result, the dialectical method was used based on the bibliographic methodology to dialogue between historical and legal concepts.

\section{THE EROSION OF REPRESENTATIVENESS IN DEMOCRACY FACING THE INTERNATIONAL ECONOMIC AGENDA MISDEEDS}

Dealing with traces of present times has always aroused caution within the researcher's profession, concerned about investigating the evolution of a given current problem, such as the effectiveness of democracy. The possibility of problematizing objects closed to the time in which the researcher writes was often avoided, in order to not running the risk of entering the fallacious trap of a purely narrative or factual investigative construction; namely, when a historical fact is analyzed, it is necessary to verify, in addition to the stages reconstruction of the event itself, the context in which the episode is located, the cultural, political and social profile of the characters involved and the possible previous events that allowed the development of the investigated fact.

In the perspective of some authors (BERNSTEIN; MILZA. In: CHAUVEAU; TÉTARD [org.], 1999), the quantitative nature of documental instruments that can be provided as sources for the researcher who is faced with the specificity of the present time, taking into account the development of the media, for example, is massive and, therefore, in order that the quantity doesn't be an impertinent factor to the profession it is necessary that new methods of analysis be discussed. At the same time, the approach of a historical context inserted in the present time puts us in contact with the condition that this history will be understood as an unfinished process (AREND; MACEDO, 2009), having assumed the fact that the analyzes produced about the present have a certain duration and may come to be modified by new developments. 
Since the Constitution of 1988 was promulgated in Brazil, in its preamble there are elements that will redefine the profile of the State model that, from that moment on, will detach itself from a legal and political order governed by the intervention of the Institutional Acts of the dictatorial regime, to then establish grounded and articulated principles for the promotion of rights and the guarantee of their inviolability. Among the foundations enshrined under the founding principles of the 1988 Constitution are specifically set out I) sovereignty, II) citizenship, III) human dignity, IV) the social values of work and free enterprise and V) political pluralism (BRASIL, 2015).

In order to establish a profile for the model of the Democratic State under Brazilian Law in the light of the 1988 Constitution, we assume the position that the principles that guide the final text of the Magna Carta are not defined only by the protection and guarantee of fundamental rights of individual character, limiting agent of state action on the individual's freedoms, or those of a social and collective character, postulated in the dictates of social and economic justice. The construction of the model of the Brazilian Democratic Rule of Law is based, mainly, on respect to its "democratic" principle, in the adaptation of popular participation to indirect (or representative) and direct (or participatory) forms, as foreseen in the Constitution 1988.

If on the basis of the Democratic Rule of Law model principles, promulgated by the 1988 Constitution, we find the traces of both a social and liberal profile, the foundation of popular sovereignty, from which all power is emanated from the people through mechanisms of representation or direct participation (art. 1, sole paragraph), ended by gratifying the inauguration of the Magna Carta with the nickname "Citizen Constitution". In this way, through the indirect (or representative) form of popular participation, the vote becomes the instrument of concretization of the democratic principle, while through the direct (or participatory) form this instrument is expressed in the configuration of a plebiscite, a referendum and even the popular initiative ${ }^{2}-$ the latter allowing direct popular expression in the proposal for drafting laws ${ }^{3}$.

Thus, the profile of the Brazilian Democratic Rule of Law is anchored both in guaranteeing and promoting rights, which are inserted in a structure that is continuously open to review ${ }^{4}$, as well as in the delimitations of popular sovereignty with regard to the limits of mechanisms of political participation. However, even if the 1988 Constitution presents such characteristics capable of restructuring - or even inaugurating - a legal and political vivacity around democracy in the country, the international situation in which the Brazilian State has been inserted since the 1970s, will intensely resonates in the ordering of conditions so that the guarantee of rights to the population and the defense of human rights take effect in the country.

From the moment that Brazil managed to overcome the impasses of the dictatorial regime, with the fall of the Berlin Wall and the collapse of socialist regimes, the international scenario of the early 1990s was driven until the present by the protagonism of a neoliberal capitalism model emerged in the 1970s - which could, in a broad way, redefine the direction of the world in the free market parameters regulated by the lex mercatoria rules, in the hope of a world faced to "peace" and "democracy" (JUDT, 2011, p. 131). And the strategy of the Brazilian State, to guarantee its place in the new directions, will not be deviated from this ideal.

In the words of Foreign Minister Celso Lafer, under the leadership of the Collor government in 1992, if, until the end of the 1980s, Brazil has as a diplomatic logic the controlled integration into the world economy, "mobilizing resources to deepen the replacement process of

\footnotetext{
${ }^{2}$ As provided in article 14 on the 1988 Constitution of the Federative Republic of Brazil.

${ }^{3}$ As provided in article 29, item XIII, regarding the organic law of the municipalities, on the 1988 Constitution of the Federative Republic of Brazil.

${ }^{4}$ Expressly, the revisions and proposals for constitutional amendments must respect the rules of constitutional provisions of stone clause, as provided in article 60, paragraph 4, of the 1988 Constitution of the Federative Republic of Brazil, namely: the federative form of State; the direct, secret, universal and periodic voting; the separation of powers; and individual rights and guarantees.
}

Revista de Direito Brasileira | Florianólopis, SC | v. 25 | n. 10 | p. 104-119 | Jan./Abr. 2020 
imports ", from 1990, with this exhausted logic, the opportunity for the affirmative fullness of the globalization logic forced the dilution of the distance between the country's internal and foreign policy (LAFER, 2007, p. 108). Therefore, the 1990s will be focused on the insertion of global themes in the country's international agenda, in a way that is no longer distant, but participatory in the political-financial pact of the post-Cold War world. Closer to the present days, Lafer defines what it would be necessary, at the beginning of the 21 st century, to preserve its own space internally in the country to deal with the demands of the new world economic logic:

Indeed, in a country like ours, development will not automatically result from the virtuous combination of fiscal, monetary and exchange rate policies, although it will find macroeconomic conditions for its sustainability in them. It requires a broad set of public policies, which in a way that is congruent and compatible with the great macroeconomic balances, which ensure currency stability, reduce inequality and boost the development of the national space, giving to the economic agents conditions of competitive isonomy, allowing them to face the challenge of globalization (LAFER, 2007, p. 121).

Despite the optimistic speech of the ex-foreign minister, in the same sense the 2008 crisis will bring to light, those ideals of a future marked by peace, democracy and free markets, with the macroeconomic balance always "regulated" and guaranteeing a competitive isonomy, twenty-two years later will prove to be no more than a mistake (JUDT, 2011, p. 131). In the complex and fragmented landscape of the first decade of the 21st century, for Luís Roberto Barroso, in fact, inequality will be enhanced "by a world order based on the imbalance of political and economic power relations", but also "in absolute control", through rich countries, multilateral finance and trade bodies, causing the blinding of the "conquests of civilization" (BARROSO, 2009, p. 306).

To face "the vicissitudes that have postponed the full democratization of Brazilian society", we must take into account, on the one hand, "the ideology of inequality", which in its economic scope will be materialized "in the abyss between those who have and those who do not have, with the consequent difficulty of establishing a common project of society" (BARROSO, 2009, p. 306). On the other hand, for the success of the confrontation, the circulation of an increasingly widespread and institutionalized corruption in the electoral, budgetary, tax and public security systems must also be taken into account. In this sense, thinking that the constitutional norms suffer from a technical inefficiency to protect the fundamental rights should not be the best path to take, especially because the norms related to these rights are free from any conditioning that may prevent them to be effectively applied immediately. Therefore, according to Bittar:

In this quadrant it is allowed to say that an unquestionable paradox is stamped on the horizon: on the one hand, fundamental rights of several carats (first, second and third generations) textually expressed in the various articles of the Federal Constitution of 1988; on the other hand, social practices outdated for at least a century in the face of the challenges (economic, political, institutional, budgetary ...) proposed by several constitutional innovations. From this mismatch the most skeptical minds are nourished, on the theoretical plane, and those who benefit from its ineffectiveness, on the practical plane (BITTAR, 2009, p. 292 - emphasis added).

Within this paradox, the added weight of the strategies articulated in favor of national development and the strengthening of a Brazilian international identity facing the current economic logic, favors even more that the balance tilts to the opposite side of fundamental rights. So, in the impasse of the mismatch between the two directions of this paradoxical horizon, the tendency of the political class to pursue an ideal development which is always far from its consummation, in reality, put it under a condition in which the guarantee and protection of fundamental rights are 
often left out. . This fact raises once again the questioning about the limits of representativeness, through the mechanisms available for political participation in the semi-direct model.

In view of this posture assumed by the Brazilian State - but not only -, the principles enshrined by constitutionalism and the guarantee of rights are strongly resisted to become effective. The intertwining of political agendas with the global economic stabilization, namely, their conformity with the international financial regulation of market relations, make "representativeness" hostage to the developmental goals concepts, weakening the structuring of a real agenda able to effect the guaranteeing rights based on social, economic and political equality.

For Noelia García-Estévez, representation is a key concept to understand "the height of citizen participation", which "intends to correct the defects of political representation that

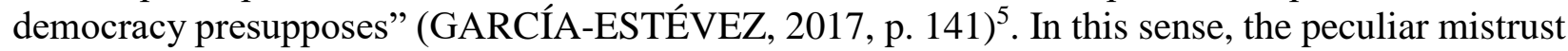
and creative capacity to mobilize individuals of the current generations facing the political detrition on representation, characterizes citizen participation as the intervention of citizens in the public sphere: "[it] is conveyed through a set of mechanisms so that the population access government decisions independently, without the need to compose the public administration or a political party" (GARCÍA-ESTÉVEZ, 2017, p. 141 - emphasis added) ${ }^{6}$.

Tony Judt is correct to note that after the fall of the Berlin Wall, on the one hand, the triumph of free markets, linked to the promises of peace and democracy, was not sustained, or at least it was not clear in his argument for "who" it was "triumphant" (JUDT, 2011, pp. 131-132). On the other hand, the collapse of communist countries revealed the death of an outdated left-wing ideology, which has now been succeeded by the need to rearticulate its proposals to oppose the abuses of financial capitalism that rules the entire modern world. From this we can infer that, if the real scope of the neoliberal triumph was not clearly evident to those who did created their argument and defend it, the troubled experience with its effects and the raw unequal reality did not result in such a metaphorical scenario. Thus, more and more,

The result is a weakened society. From the point of view of those below - in need of unemployment insurance, medical care, social benefits or other officially mandatory services - it is no longer instinctively for the state, government or public administration to resort. The service or benefit in question is now "provided" by a private intermediary. As a consequence, the dense network of social interactions and public goods has been reduced to its minimum, with nothing linking the individual to the State, except authority and obedience (JUDT, 2011, pp. 115-116).

Faced with the minimalization of popular social interactions with public administration, from the second decade of the 21st century, large portions of world population and social movements of different ideological tonalities had manifested themselves based on new foundations and new political practices, since their representation - previously conflicted - shows itself on the verge of nonexistence. We can perhaps say that a first concern could have arisen from these new movements: "It doesn't the case that the forces of financial globalization are taking the risk of leading to a capital concentration even bigger than all those observed in the past, does it - perhaps it took place already -?" (PIKETTY, 2014, p. 419).

Two pathways identify the strategic power of the State, the first being partisan improvement which, through social movements such as NGOs, opens space for pressuring the public power - its budget - in order to improve democracy and fight corruption. A second way is

\footnotetext{
${ }^{5}$ Free translation of: "La participación ciudadana intenta corregir los defectos de la representación política que supone la democracia".

${ }^{6}$ Free translation of: "[...] se vehicula a través de un conjunto de mecanismos para que la población acceda a las decisiones del gobierno de manera independiente sin necesidad de formar parte de la administración pública o de un partido político".
}

Revista de Direito Brasileira | Florianólopis, SC | v. 25 | n. 10 | p. 104-119 | Jan./Abr. 2020 
the implementation of social and economic rights (PINSKY; PINSKY, 2016, p. 563). Thus, in the current scenario of financial governance over the State, such strategies are dissolved, or, in some way, we can say it changed its focus. But when it changes its focus, can also open space for new questions about political participation to emerge. This is what we will see in the next chapter.

\section{SOCIAL MOVEMENTS, INTERNET AND THE EMERGENCE OF NEW POLITICAL ACTORS}

In view of the controversial circumstances that Brazil has been subjected, in the last six years (since the June Days, which through the intense use of cyberactivism in social networks has integrated protests across the country around not only the increase in bus tickets, but of a whole range of demands developed in this process; for the structuring of the investigative initiative of public money laundering and bribery of Lava-Jato Operation; for the presidential disputes and state elections in 2014, the repercussion of the opening of the impeachment process against President Dilma Rousseff - also intensified by cyberactivism -, in 2015, and the effect of her removal from the government in August 2016, the negativity of public opinion around the program of the government of Michel Temer, in view of the measures of the proposals in process PEC 241/16 and MPV 746/16, submitted for voting without public consultation and endangering the protection and guarantee of conquered rights; and, currently, by the use of social networks such as Facebook, What'sApp and Twitter as instruments of electoral campaign by the governments of the then presidential candidates Jair Messias Bolsonaro, in Brazil (2018) and Donald Trump, in the USA (2016)), the debate about the effectiveness of the instruments available to support the principles of democracy and to questioning the effectiveness of participation and political activism as a democratic practice is fundamental.

In the scenario of a State hostage to the strategies of financial speculation, at the same time that the available mechanisms for political participation seek to establish accountability for political representation in the hands of the electorate, the very vote of confidence deposited in the elected representatives suffers from authority when face the insufficiency of mechanisms capable of containing the possible misconduct by these representatives. In this perspective, the leading role of national and international financial speculation, increasingly present in the country's economic and political life, further intensifies the loss of authority degree in the vote of confidence enshrined to the concept of representation, highlighting the limits of effectiveness in the current Brazilian legal system to meet social demand.

Along with what constituted the drafting of the 1988 Constitution, through the institution of democracy in the Brazilian political scene, from the 1990s onwards, a new characterization of social movements has been evident by the tendency they assumed in formalizing the role of interlocutors among the population and the state. In the context of the 1990s, after the fall of the Berlin Wall and within a state with a newly conquered democracy, in Brazil social movements began to contemplate a new characterization, assuming the role of interlocutors between the population and the State, in the search for guaranteeing access to the rights enshrined in the Constitution (GOHN, 2014, pp. 322-323).

This role will serve to develop a posture aimed at questioning and elaborating a structure - continuously mobile - of claims based, therefore, on the democratic principles safeguarded by the text of the 1988 Constitution. Thus, in the direction of movements such as the Movement of Landless Rural Workers (MST), linked to the traditional model of struggle for agrarian reform, or to the general agenda of workers movements, in this period, several citizen movements and NGOs begin to strengthen a position of collection and pressure for the guarantee and enforcement of their rights, now sheltered by law. The action tactics developed by these movements were articulated in 
order to infiltrate among the State's governance strategies, in turn increasingly biased by the abuses of financial speculation.

Appropriating the conceptual apparatus used by Michel de Certeau to explain the concepts of strategy and tactics, the understanding of the clash in which the principle of political participation is inserted can find more adequate foundations. At first, Certeau defines the concept of strategy as the calculation or manipulation that can postulate its own place, being "capable of serving as a basis for the management of its relations with a distinct exteriority" and which becomes possible when a subject of will and power "is isolable from an 'environment"' (CERTEAU, 2012, p. 45). The political and economic nationality, company or scientific foundation can become this subject of power. The tactic, on the contrary, is distinguished as a calculated action or an operation that does not have a place as its "own", having only the place of the other. Which means that if the game itself is always a victory over the time, tactics must constantly play with events in order to turn them into "occasions". In other words, "tactics are the art of the weak" (CERTEAU, 2012, p. 95).

The appropriation of these two types of operations (strategies and tactics) can serve as a basis for attributing, on the one hand, to the Brazilian State, through its representation as a Democratic Rule of Law (a discursive place as "its own"), the role to calculate the power relations, using all the strategic apparatus available to maintain the management of its relations with the population (a distinct exteriority). In this respect, the structure of the laws in the Constitution and the validity of the competent bodies to apply it are not only willing to affirm a specific model ("Democratic of Law") of management, but mainly to maintain the management of the State's relations with the population. On the other hand, if the population is restricted to a structure of rights and duties in the text of the 1988 Constitution, in the representative model of popular sovereignty it is continually dependent on the calculation made by those to whom the vote of confidence was deposited. In this way, the population is at the mercy of a place circumscribed as "their own" and, as in tactics, it depends on the other (the elected politician and the institution of the three Powers) to obtain their profits, namely, their rights and guarantees.

The increasing increase in popular discrediting in relation to the current political class caused the Brazilian population, in the format of social movements, to be vigilant with regard to the "possibilities of gain", at first, through the traditional means representing the short time of the elections, of eventual plebiscites and referendums, the bureaucracy of proposing bills. However, the possibilities of gain are available, including, through events that at some point in their trajectory give rise to the "occasion" of pressure from the public authorities, such as the example of street occupations from the June Days (2013) ), the protests against or in favor of the impeachment process of President Dilma Rousseff (2015), the parliamentary and popular controversies of the government of Michel Temer (2016-2019), the struggle for the approval of labor and social security reforms, the latter being taken to the current government's agenda (2019-2020) and approved in the face of even more intensified protests.

In Certeau's words, the use of tactics operates "blow by blow, move by move", having to use the flaws "that the particular circumstances are opening up in the surveillance of the proprietary power". Thus, from the moment that the current political class shows its (strategic) "failures" in the exercise of the representativeness to which it was elected, social movements find the manifestation at the "occasion" of inequalities and in the absence of representativeness, "possibilities offered for an instant" (CERTEAU, 2012, pp. 94-95). At this point, the axis of the debate around political participation brings to the field of analysis the circulation of social movements, organized or not, which often call into questioning the effectiveness of the current state model and convey alternative proposals for political reform and the central involvement of the popular initiative in guaranteeing the rights enshrined in law, but even in those to be still conquered. 
Therefore, demands for a new model of political participation are increasingly present on the agenda of the different types of social movements and Non-Governmental Organizations, exposing the current model of participation (in its indirect and direct format) an increasingly intense and fragile in the attribution of the guarantee and defense of the rights enshrined in the 1988 Constitution.

In the midst of the financial crisis of 2008, movements such as the Arab Spring, the Pot and Pans Revolution, in Iceland, the Indignados, in Spain, Occupy Wall Street, in the USA, and the June 2013 Days, in Brazil, once again put evidently, with great impetus, that the excesses practiced by the uncontrolled speculation of the financial market and the involvement of the political classes of the State with the logic of the markets end up introducing great obstacles in the face of guaranteeing the fundamental rights of the population. About some of these movements in the context of the financial crisis, activism proved to be strongly idealized around the principles of autonomy, independence, horizontality, solidarity and the use of cyberactivism as an action methodology, the use of such elements varies, being appropriate in different nuances.

For Rodrigo Sandoval-Almazan, he points out that the use of technology for social protests is a different aspect in the political scenario, showing a clear empowerment of citizens' organizational capacities, as well as the sharing of ideas "and collaboration to achieve collective goals" (SANDOVAL-ALMAZAN, 2016, p. 73).

At this point, it is important to highlight the pioneering use of the internet by the Zapatista National Liberation Army (Ejercito Zapatista de Libertación Nacional), in Mexico, for the communication, dissemination and organization of the guerrilla movement.

In order to have a clear idea of this pioneering spirit, in $1994^{7}$, in January, the Zapatistas launched on their website their first manifesto of struggle entitled First Declaration of the Lacandona Jungle (ENLACE ZAPATISTA, 1994).

In some cases, such as on Occupy Wall Street and on the platform Democracia Real YA!, by the Indignados, the discontent discourse in relation to the political class and the result of social, political and economic inequalities resulting from this position and unrestrained financial speculation, will be reinforced. Still in these movements, the instrumentalization of cyberactivism will be a determining element for the development of its goals, given the impetus for a real-time interaction with the digital public that accesses their respective channels of dissemination. In the example of movements such as the Movimento Passe Livre in São Paulo, the Assembleia Nacional dos Estudantes - Livre and the collective Juntos!, shyness in the development of the mentioned elements will reveal, to a greater extent in the last two cases, a strong link to party programs traditional and, in all, a cyberactivism that, in practice, will have a little impact on the interaction with the digital public involved (BRAGA, 2016).

However, when we analyze today (a few years after the Jornadas) the use of social networks such as Facebook, Twitter and What'sApp by a population with a decentralized profile and not organized in social base movements like those mentioned in the Brazilian case, we see a connection most advanced of cyberactivism. Therefore, based on the studies developed on the impact of technology on communication and politics, strictly speaking from the new millennium onwards, it is possible to highlight the bet on the use of virtual technologies as a potential instrument capable of facing the wear of the contemporary political communication and create a democratic practice that would concretely effect a political experience based on the principles of popular sovereignty.

\footnotetext{
${ }^{7}$ It is also important to note that in SANDOVAL-ALMAZAN (2016), the author traces the actions of the Zapatista Army of National Liberation to the year 1995. However, next to the movement's website, it is possible to trace the date of the first publication on January 1, 1994. Available in: http://enlacezapatista.ezln.org.mx/1994/01/01/primeradeclaracion-de-la-selva-lacandona.
} 


\section{CYBERACTIVISM AS A NEW TACTIC OF POLITICAL PARTICIPATION?}

When the strategies of financial speculation and the minimum state take over the political governance of public administration, new ways of putting democratic practices into effect appears in order to renew and strengthen social justice. And, given the circumstances that will progressively direct the Brazilian political scenario in the corruption scandal of the political class and, at the same time, promote the distrust of the authority of the vote of confidence deposited in the elected representatives, accused of conducting governance for profit, we adopt the hypothesis that, nowadays, the resignification of the content present in the demands of social movements and even the concept of political activism has been taking shape.

Regarding the re-signification of the concept of political activism, nowadays the use of technologies appears to us as a new proposal among the movements of citizens, but not only, being activate even among strategies of electoral campaigns by some political figures.

However, for Noelia García-Estévez, the approach to the different modalities of social action through the internet reveals a development in at least two groups or strands of activism: cyberactivism and hacktivism, on the one hand, and slacktivism, the clicktivism and hashtag activism, on the other.

If we have that cyberactivism makes use of the internet and information and communication technologies, in general, as valid instruments in the search to achieve political and social objectives, the way of dealing with these is expanded and evolves according to the use by different social actors. Among the main tools that came into play were: a) SMS; b) electronic mail (e-mails); c) social networks; d) signing petitions; e) collective polling applications (ex.: Appgree); f) protest videos viralized on the web (YouTube); g) podcasts; h) memes; i) sarcastic images; j) personal and corporate blogs; and k) IRC channels ${ }^{8}$ (GARCÍA-ESTÉVEZ, 2017, p. 147).

Hacktivism as activism has more sophisticated elements of action. Its users have in-depth computer knowledge, enabling a more open range for the effective use of ICTs and networks. Specifically

The members of this movement start from a collective conscience and acquire a socially committed attitude, placing their knowledge at the service of citizenship and promoting policies such as freedom of expression, human rights and information ethics (GARCÍA-ESTÉVEZ, 2017, p. 148).

The difference between hacktivists and the classic "hackers" of the technological underworld, is that the second type of activists tends to present themselves as an "apolitical character", concentrating their actions in the search for individual gains, for a specific group or for the liberation information.

For the first group, hacktivists, there are three ways of channeling their actions: a) that of solidarity, as belonging to the same society; b) conflict with an opponent over resources that both value; c) break with the limits imposed by the system to be "invaded" by its mobilization. Their types of attacks are: a) DDoS attacks (Distributed Denial of Service Attack) ${ }^{9}$; b) netstrike attacks ${ }^{10}$;

\footnotetext{
${ }^{8}$ IRC stands for Internet Relay Chat, a network of servers that host chat channels, that is, the rooms where conversations take place. Source: https://www.tecmundo.com.br/web/1493-o-irc-nao-morreu.htm.

${ }^{9}$ A distributed denial of service attack can simply restart the servers or can cause the system behind the website to crash completely. Source: https://www.tecmundo.com.br/seguranca/10970-ddos-como-funciona-um-ataquedistribuido-por-negacao-de-servico.htm.

${ }^{10}$ About Netstrike: "The meaning of the operation isn't so much flooding the server as it is to circulate the reasons for the protest as widely as possible, stimulating a debate. The same holds for demonstrations: the aim isn't to block city traffic, but to focus attention on certain problems, make them visible and reach as many people as possible" (BAZZICHELLI, T. 2008, p. 173).
} 
c) use of exploits ${ }^{11}$; d) doxing ${ }^{12}$; e) copwatching $^{13}$; f) fakes ${ }^{14}$; g) redirection of institutional or official web pages; h) development of software tools; i) data theft, etc. (GARCÍA-ESTÉVEZ, 2017, p. 150).

As we approach another activism group, the slacktivism, clicktivism and hashtag activism strands - the last two arms of slacktivism - make up the group called "coach activism"15, that is, a modality that it offers a low commitment impact and little transformation capacity (GARCÍAESTÉVEZ, 2017, p. 151).

Alongside solidarity slacktivism, slackers develop actions limited to petition signatures, copy information to their personal pages on social networks, change the theme or personal data of social profiles, "like" on Facebook, Twitter and Instagram, help to viralize hashtags about some content, share videos via What'sApp, small donations of money, upload photos or selfies in support of a cause and perhaps create them on Facebook.

Basically, clicktivism aims to gather the greatest number of "clicks" from people in support of a cause, a petition or any call for action, which, according to García-Estévez, citing a UNICEF statement to his supporters, may not create no real impact on the transformation of the real world.

Finally, hashtag activism is committed solely to the inclusion of hashtags ${ }^{16}$ that convey support for claims that support some cause, via social networks (GARCÍA-ESTÉVEZ, 2017, p. 152).

In the previous chapter, when we are referring to a certain "advance" in the interplay of cyberactivism, we do not refer to a positive or even a negative advance, but, as a starting point, mostly to a more routine familiarization with the use of the internet in different aspects of social experience, rather than between social movements organized around specific protest platforms and basic ideologies.

Since the development of new forms of political participation and the creation of new forms of interaction between governments and society, they become fundamental initiatives for the survival of representative sovereignty, under the terms of the Democratic Rule of Law model attributed to the Brazilian State, it is worth to emphasize that at the moment in which such new forms of participation and interaction are stipulated, for most of these authors, it should be considered that their structuring would become more effective if stimulated, more than the direct interaction of the population with political representatives, a more participatory democracy in the popular deliberative sense of social construction of representation. According to Ituassu,

In the midst of this debate, it is argued here that the contribution of digital political communication to democratic representation is less in establishing more direct links, or interactivity between representatives and represented, and more in strengthening, in addition to liberal precepts, digital practices of deliberation and participation in representation, which could generate denser forms of

\footnotetext{
${ }^{11}$ Exploits are a subset of malware. They are usually malicious programs with executable data or code capable of taking advantage of system vulnerabilities on a local or remote computer. Source: https://www.kaspersky.com.br/blog/exploits-problem-explanation/6010/.

${ }^{12}$ Doxing refers to the practice of using the internet to collect and collect personal and private information and then publicly disclose that information online. Source: https://www.tiforense.com.br/o-que-e-doxxing/.

${ }^{13}$ Copwatching is a media-based strategy of using online broadcasts to expose and monitor police online. Source: http://www.ihu.unisinos.br/entrevistas/522986-os-escrachos-e-um-novo-fenomeno-de-participacao-social-entrevistaespecial-com-ivana-bentes.

${ }^{14}$ About the fakes or fake news, we'll talk later.

${ }^{15}$ Free translation of "activismo de sillón”, in (GARCÍA-ESTÉVEZ, 2017, p. 151).

${ }^{16}$ Hashtag is a term or expression preceded by the hash symbol (\#) used on social networks in order to direct the user to a page of publications related to the same topic or discussion. It is used on Facebook, Twitter, Instagram and other social media. Each created hashtag is transformed into a hyperlink that will direct the search to all people who have also marked their content with that specific hashtag. Source: https://rockcontent.com/blog/o-que-e-hashtag/. 
responsiveness on the part of representatives and more opportunities, on the part of those represented, in the processes of social construction of representation (ITUASSU et, al., 2015, p. 127).

Thus, emphasizing the participatory value that the instrumentalization of technologies can offer to make democratic practices effective, we can observe how the use of social networks allowed that, through unorganized movements in society - namely, people not organized in social movements or acting around specific agendas -, they brought up the election of presidents such as Donald Trump, in the USA (2016) and Jair Messias Bolsonaro, in Brazil (2018). For the type of campaign called "hypermedia" and which marks the latest generation of political strategy for elections, its main attribute is the use of Big Data. With the pioneering use of Big Data in communication and political marketing actions of the campaign of President Barack Obama, Trump's predecessor in the USA, this digital analysis tool allows the data fed by the internet users themselves on digital platforms to be used as a raw materials for use in election campaigns.

Since 2007, news and protests against data surveillance and the violation of privacy by various internet services have gained prominence, mainly in the academic field. These discussions became broader with the denunciations made by former National Security Agency (NSA) technician Edward Snowden of the surveillance carried out by the American government through the Prism (Surveillance Program), which were intended to track government data and actions. and people from different countries, in the most varied information and communication environments. This episode highlights the discussions about the concept of privacy, especially in digital social networks, a concern that, although legitimate, is limited if it is not accompanied by a broader problematization of the characteristic processes of digital surveillance (ANTONIUTTI; ALBAGLI, 2014, pp. 2337-2339).

In the case of the Obama campaign, the direction of the information collected through social networks, or even, through sources such as cellphone (What'sApp), direct mail and consumer analysis companies, for example, was server to a cloud database (central server) and analyzed by the candidate's data analysis team. The set of information collected set up a structure capable of making the target voters visible, as well as "the best way to retain them with the figure of the president and his campaign proposals", and it is even possible to find possible community leaders, "supporters of Obama's ideas and key people in political articulation in every city and location in the United States" (ANTONIUTTI; ALBAGLI, 2014, p. 2337).

Rodrigo Sandoval-Almazan argues that the use of social communication networks, using instruments such as video-blogs (Vine), online chat (Snapchat and What'sApp), YouTube, Twitter and Facebook as a political strategy, had the 'springboard' "The success of the Barack Obama campaign. And the case of the Trump Vs Clinton presidential dispute is no exception in the use of this political strategy: in fact, such a campaign "increase the use of this digital spaces to continue the debate and expand the ideas of this two candidates" (SANDOVAL-ALMAZAN, 2016, pp. 7273).

For the elections of Donald Trump, in 2016, in the USA, and Jair Messias Bolsonaro, in 2018, in Brazil, ended to continue the same feature of Big Data. In the Donald Trump campaign, his team had Brad Parscale, a specialist in digital marketing, using data appropriation through Facebook as a central strategy. One of the instruments used by Parscale were the so-called dark posts, posts that are likely to contain negative information about the opponent's campaign and are visible only to those who were directed; another member of the Trump team was Steve Bannon, who in partnership with Cambridge Analytica, had access to large databases with individualized information from Facebook users and other social networks. The same company would have 
confirmed its partnership, in 2017, with a Brazilian company to operate in Brazil, through the firm CA-Ponte, but which had its operation canceled and the organization's subsequent closure, with the scandal surrounding the data leak (ITUASSU et. al., 2019).

Another instrument used in the Donald Trump campaign, presented by evidence, was the spread of fake news through partnerships made by the candidate's team, during the election.

In Brazil, on the other hand, the use of digital media in electoral campaigns is not a recent phenomenon, as is the use of fake news and robots (bot) that act as dispersers of information as "fantasy users". However, for the year 2018, in the context of electoral dispute reforms in electoral law $n^{\circ} .9,504$ / 97 (through Law no. 13,488 / 2017) allowed the "boosting of content", "as a form of electoral propaganda", leading, according to Arthur Ituassu, the candidate Jair Messias Bolsonaro to have his campaign victorious in the presidential elections of 2018 (ITUASSU et. al., 2019, p. 10).

As in the Trump electoral campaign, Bolsonaro's campaign was attributed to "computational advertising in the form of robots operating in networks, fake news and manipulation through algorithms", however, in the case of the Brazilian candidate, through Facebook monitoring, it was shown that "an advertising tactic like the Donald Trump campaign in 2016, with the sending of microdirect advertising" was not used, and in the context of the 2018 elections, Bolsonaro already obtained "a consolidated position" in this social network, "Worked over the years, and far superior to that of his opponents". Otherwise, the most centralizing social network of Jair Bolsonaro's campaign was What'sApp, which does not offer the possibility of advertising or even targeting, as it is an encrypted messaging application, and the information is only disseminated if any user passes it on or through a mass message, "bumping into" the electoral norm, which prohibits sending messages to numbers that were not voluntarily assigned to the campaigns" (ITUASSU et. al., 2019, pp. 11-12).

As we have seen so far, the discussion we have woven around the appropriation of Big Data as an electoral communication tool makes us observe that, in the opposite line of what was expected by the mentioned authors, the possibility of using technology as a way to carry out a more effective democratic experience, may have been replaced by bias in public opinion and conditioned the very power of election of potentially voting citizens. Thus, there has been much less, up to the present moment, the creation of a participatory democracy able to provide a real deliberative power for the people and more "direct interaction" of the population with their political representatives, or better, with the result of carefully collected information to co-opt voters for possible electoral gains.

At this point in our debate, the question that could come to mind would be: can cyberactivism reveal itself as a new tactic of political participation? In the face of the crisis of representativeness in relation to the political class and the fierce criticism of the excesses of financial speculation on the government of States, the pre-election events of Trump and Bolsonaro, such as the Pot and Pans Revolution, the Arab Spring, the Indignados of Spain and the Occupy Wall Street, mentioned above, demonstrated that the power of social networks has an immeasurable potential for democratic "gain", having even demonstrated concrete results, such as the case of the Icelandic Constitution created through Twitter and the election of a platform generated in protests of the Indignados in Spain.

Through cyberactivism, the examples show that opportunities were taken advantage in the short time they lasted, on the other hand, since the "cracks" of the occasion were closing in to the gain opportunity, the power structure of the states still hostage - or even more - from the abuses of national and international financial speculation, was able to renew its strategies based on the tactics used by cyberactivist social movements and, therefore, a new occasion is needed to be able, once again, to put into practice tactics that can move a little closer to the gain of a participatory and fair democracy, in fact. 
It remains to be seen, finally, whether we will also be able to provoke a gain "occasion" and, with luck on the right movement, to effect a satisfactory result so that new occasions only make it possible to reinforce the values and practices of an effective democracy, worthy of endorsement the consolidation of fundamental rights enshrined in the model of the Democratic Rule of Law.

\section{FINAL CONSIDERATIONS}

A world managed by profit from the lucrative bets of the financial market, this is our reality, which in itself would have no problem, considering the need we have for a developed country to generate the social welfare desired by the utopia of democracy. The problem occurs when the focus of progress rests less on social well-being and puts all its energies in the centrifugal growth of profit away from the vital survival needs of human beings.

As highlighted in the content of this research, with the exception of the principles of obedience and state authority over society, the thick network of interactions and constructive conflicts developed throughout the history of democracy in the modern world was, in a few decades, reduced to a minimum, to the point of showing itself on the verge of nonexistence. The advent of cybernetic technologies has made us all inhabitants of the web, conforming us to an existence based on the internalization of new languages (in bytes vocabulary) and which instrumentalized us to intertwine new practices not only of living in daily life, but mainly for deal with the social conflicts of the democratic experience.

Against the traditional strategies stipulated as a function of the Democratic Rule of Law, namely, the strengthening of popular party representation, the articulation of social movements trained to pressure public power and the implementation of social justice, what we find is that the financial speculation strategies on the autonomy of the state prevailed and new ways of carrying out democratic practices appear as necessary for the renewal of dormant democratic values.

After observing the advent of cyberactivism as a new form of popular participation in democracy, based on the examples cited of social movements in the internet era, it was possible to consider a limitation on the field of popular action to pressure the public authorities for justice social, but also an increase facing the potential that digital world presents for a new articulation of the very sense of political activism. On the other hand, perhaps still stunned by the explosion of the intense use of cyberactivism as an instrument of protest by the social movements in digital age, between the years 2009-2014, and seeking to understand until now the processes that have led the world to witness this phenomenon, it was not noticed that outside the classic model of organization of social movements and far beyond the characters starred in the different episodes, new internet users are ruling.

Well, if it was not possible to follow and still understand the phenomenon of cyberactivism today and not even the appearance of these new characters on the scene (ordinary people not organized in movements structured around specific guidelines), perhaps it was due to the lack from a more accurate look and less blurred by the euphoria of expectations of "gain", in moments of conflict, on the part of those who seek social justice. In the opposite wake of this conflict, however, the development of Big Data as an instrument for analyzing information from internet users to direct the result of information to co-opt voters for possible electoral gains, reveals, by itself, that the strategic view of political elites and financial were, in turn, very attentive to this new audience. To the point that the improvement of control over popular will on the part of this elite allowed the election of candidates such as Donald Trump and Jair Messias Bolsonaro, in a time when social networks were used as a rich source to create a social upheaval around the election campaigns. 
It is important to point out that, in these final considerations, the fact that Big Data was used to direct the public opinion of these other users (ordinary citizens) does not attest that these characters are passive and non-reactive citizens to social injustice, on the contrary, the use of Big Data exposes the reality of the financial elites using the opportunity to know what these users thought and, from the information collected, were able to formulate a campaign that corresponded to the language of their expectations.

Therefore, in order to be able to reinforce the values and practices of a democracy that can be named, in fact, as effective, through the consolidation of the fundamental rights of the Democratic Rule of Law, it is also necessary to be aware of the possibility that there may be other popular agendas who are wanting to be part of the traditional democratic agenda, but who are only finding support in governments with a more aggressive position in the way of doing politics.

\section{BIBLIOGRAPHIC REFERENCES}

ANTONIUTTI, C. L.; ALBAGLI, S. O uso do Big Data em campanhas políticas eleitorais. Anais do XV Encontro Nacional de Pesquisa em Ciência da Informação: além das nuvens, expandindo as fronteiras da Ciência da Informação, 27-31 out., Belo Horizonte, MG. 2014.

AREND, S. M. F.; MACEDO, F. Sobre a história do tempo presente: entrevista com o historiador Henry Rousso. Tempo e Argumento. Revista do Programa de Pós-Graduação em História. Universidade do Estado de Santa Catarina, Florianópolis, v. 1, n. 1, pp. 201-216, jan./jun. 2009. Available in: http://revistas.udesc.br/index.php/tempo/article/viewFile/705/608. Acesso em: 25 Out 2019.

BARROSO, L. R. Interpretação e aplicação da Constituição: fundamentos de uma dogmática constitucional transformadora. 7. ed. São Paulo: Saraiva, 2009.

BAZZICHELLI, T. Networking: The Net as Artwork. Aarhus, Denmark: Digital Aesthetics Research Center; Aarhus University, 2008.

BÉDARIDA, F. Tempo presente e presença da história. In: FERREIRA, Marieta de M.; AMADO, Janaína. Usos e abusos da história oral. 5.ed. Rio de Janeiro: Ed. FGV, 2002.

BERNSTEIN, S.; MILZA, P. Conclusão. In: CHAUVEAU, A.; TÉTARD, Ph. (org.). Questões para a história do presente. Tradução Ilka Stern Cohen. São Paulo: EDUSC, 1999.

BITTAR, E. C. B. O direito na pós-modernidade e reflexões frankfurtianas. 2. ed. Rio de Janeiro: Forense Universitária, 2009.

BRAGA, J. T. Movimentos sociais na era da internet: uma leitura comparativa da ação política nos protestos das Jornadas de Junho, no Brasil, dos Indignados, na Espanha, e do Occupy Wall Street, nos EUA. 2016. 136 f. Dissertação (Mestrado em História) - Programa de Estudos PósGraduados em História, Pontifícia Universidade Católica de São Paulo, São Paulo, 2016.

BRASIL. Constituição da República Federativa do Brasil. 47. ed. Brasília: Câmara dos Deputados; Edições Câmara, 2015. 
BRAUDEL, F. Escritos sobre a História. São Paulo: Perspectiva, 2011.

CASTELLS, M. Redes de indignação e esperança: movimentos sociais na era da internet. Tradução Carlos Alberto Medeiros. Rio de Janeiro: Zahar, 2013.

CERTEAU, M. A invenção do cotidiano: 1. Artes do fazer. Tradução de Ephraim Ferreira Alves. Rio de Janeiro: Vozes, 2012.

ENLACE ZAPATISTA. Primera Declaración de La Selva Lacandona. 01 jan. 1994. Available in: http://enlacezapatista.ezln.org.mx/1994/01/01/primera-declaracion-de-la-selva-lacandona.

GARCÍA-ESTÉVEZ, N. Origen, evolución y estado actual del activismo digital y su compromiso social. Ciberactivismo, hacktivismo y slacktivismo. II Congreso Internacional Move.net sobre Movimientos Sociales y TIC, Grupo Interdisciplinario de Estudios en Comunicación, Política y Cambio Social de la Universidad de Sevilla (COMPOLÍTICAS). Sevilla: 2018, pp. 139-156.

GOHN, M. da G. Teorias dos movimentos sociais: paradigmas clássicos e contemporâneos. 11. ed. São Paulo: Loyola, 2014.

HOBSBAWM, E. J. Sobre a história. São Paulo: Companhia das Letras, 1998.

IBRAHIM, Y. Politics, protest, and empowerment in digital spaces. Hershey, PA (USA): Information Science Reference, 2017.

ITUASSU, A et. al. De Donald Trump a Jair Bolsonaro: democracia e comunicação política digital nas eleições de 2016, nos Estados Unidos, e 2018, no Brasil. $8^{\circ}$ Congresso

COMPOLÍTICA, Brasília - DF, 15 a 17 de mai. 2019. . e-Representação como comunicação política: Internet e democracia representativa,

Famecos, Porto Alegre, v. 22, n. 2, abr./mai./jun. 2015.

JUDT, T. O mal ronda a terra: um tratado sobre as insatisfações do presente. Tradução Celso Nogueira. Rio de Janeiro: Objetiva, 2011.

LAFER, C. A identidade internacional do Brasil e a política externa brasileira: passado, presente e futuro. São Paulo: Perspectiva, 2007.

PIKETTY, T. O capital no século XXI. Tradução Monica Baumgarten de Bolle. Rio de Janeiro: Intrínseca, 2014.

PINSKY, J; PINSKY, C. B. (Org.). História da cidadania. 3. ed. São Paulo: Contexto, 2016.

SANDOVAL-ALMAZAN, R. Political messaging digital spaces: the case of Twitter in Mexico's presidential campaign. In: IBRAHIM, Y. Politics, protest, and empowerment in digital spaces. Hershey, PA (USA): Information Science Reference, 2017. 